\author{
Agnieszka Orankiewicz \\ University of Lodz \\ e-mail: agnieszka.orankiewicz@uni.lodz.pl \\ ORCID: 0000-0001-8718-935X
}

\title{
Maciej Turała
}

University of Lodz

e-mail:maciej.turala@uni.lodz.pl

ORCID: 0000-0003-1054-8048

\section{THE DEVELOPMENT OF CITIES IN POLAND - THE ROLE OF EDUCATION}

\section{POTENCJALY ROZWOJOWE MIAST - ROLA EDUKACJI}

DOI: 10.15611/pn.2019.7.21

JEL Classification: H52, H75, I25, I28

Summary: The discussion presented in this paper originates from the identification of three development potentials of cities: innovation-based, culture-based and education-based. The paper tackles the problem of determining the importance of primary, secondary and higher education for the development of cities. The main objective of the paper is to create a method for the measurement of education-based potential for development in Polish urban communes. To that end, five development factors encompassing 12 diagnostic variables were identified and a City Education Potential (CEP) index was constructed and its values calculated for 303 urban communes in Poland between 2013 and 2016. The CEP index was then used to: (1) prepare city rankings, (2) identify differences between small, medium-sized and large cities as well as (3) determine the significance of each diagnostic variable in each of the analysed size categories. The last part of the article also highlights the differences between regions in terms of the education-based potential of urban communes.

Keywords: city, education, development.

Streszczenie: Punktem wyjścia niniejszych rozważań jest wyróżnienie trzech potencjałów rozwojowych miast, opartych na innowacjach, kulturze i edukacji. Artykuł podejmuje problematykę określenia znaczenia edukacji i kształcenia wyższego dla rozwoju miast. Celem artykułu jest znalezienie metody pomiaru potencjału edukacyjnego gmin miejskich w Polsce. W opracowaniu zostały zdefiniowane czynniki mające wpływ na jego wielkość oraz został zbudowany miernik potencjału edukacyjnego miast. Badaniu poddano 303 gminy miejskie w latach 2013-2016. Dzięki zastosowanej metodzie opracowano rankingi miast według potencjału edukacyjnego oraz przeprowadzono analizę z uwzględnieniem wielkości gmin 
i istotności zmiennych diagnostycznych dla poszczególnych grup wielkości. W ostatniej części określono zróżnicowanie regionów ze względu na potencjał edukacyjny gmin miejskich położonych na ich terenie.

Słowa kluczowe: miasto, edukacja, rozwój.

\section{Introduction}

Fostering the creation of a knowledge-based economy has become one of the main challenges facing both countries as well as regions in the $21^{\text {st }}$ century. The knowledgebased economy concept was popularised by P. Drucker (1994) who highlighted the emergence of the knowledge society era. This concept was widely discussed by many authors also in the context of city development (for example, see (Lazzeretti and Tavoletti, 2005; van Winden, van der Berg, and Pol, 2007; Eriksson and Forsberg, 2010; Joshi, 2017).

Knowledge is an integral part of broadly defined human capital which may be perceived and analysed as a feature of individuals, economic entities or even entire economies (Gołaszewska-Kaczan, 2014, pp. 92-93). Regional science recognises human capital as one of the core components of territorial capital, alongside natural resources, endowments of public, private and mixed goods, social capital, relational capital as well as cognitive capital (Jona, 2015, pp. 102-104; Przygodzki, 2015, p. 30). The endowments of human capital and its spatial distribution are affected by two main types of processes: the first relates to the creation of human capital, i.e. education, and the second concerns its movements, i.e. migration (Czapiewski, 2013, p. 8).

Many researchers point to the direct as well as the indirect relationships between education, including university level education, and the creation of human capital (among others Burgess, 2016; Stępień and Poszwa, 2016) and - as a consequence development (for example Gennaioli, La Porta, Lopez-de-Silanes, and Shleifer, 2011, pp. 46-47). Others emphasise the interdependencies between education on all levels and the competitiveness of countries, territorial units and individuals. Researchers pay particular attention to higher education institutions the activities of which contribute towards five out of the twelve pillars of the national economies' competitiveness level measured by the Global Competitiveness Index: (1) institutions, (2) higher education and training, (3) labour market efficiency, (4) technological readiness and (5) innovation (Badea and Rogojanu, 2012, pp. 131-133).

As Faggian and McCann (2009) point out, "there is increasing evidence to suggest that the role played by human capital in cities has increased over recent decades". Given that ensuring access to education is the fundamental channel by means of which the public authorities may affect how human capital is created and shaped, understanding the determinants of education-based potential for cities' development is one of the foundations for formulating local and regional development policies. 
Given the above, the article aims at outlining a method for the measurement of education-based potential for cities' development, applying this method to Polish urban communes and ranking them using the City Education Potential (CEP) index. It is assumed that the education-based potential for cities' development is one of the leading determinants, alongside the innovation-based and culture-based potentials (see also Orankiewicz and Turała, 2019). In the first step a number of diagnostic variables were determined with the use of which the education-based potential for development is reflected. Then an aggregate measure is created and analysed for urban communes divided into three size categories (small, medium and large) as well as per region.

The research is based on data for 306 urban communes in Poland. The data was collected for the period from 2013 to 2016. Three urban communes changed their administrative status from urban into urban-rural during this period, hence the final results are based on data for 303 territorial units.

\section{Education-based potential for cities' development - measurement}

The education-based potential for cities' development may be perceived as the education sector's capacity to provide educational services (Kwiatkowski and Roszkowska, 2008, p. 2). In order to measure this potential we decided to use 12 diagnostic variables grouped into five groups or factors related to: preschool education, primary education, secondary and post-secondary education, higher education and education-related expenditure carried out by urban communes.

Our approach to the measurement of the education-based potential for the development of cities is based on a set of diagnostic variables which allow for an assessment of the educational base in each of the analysed communes. The authors concentrate on institutions which are perceived as transmitters of competences in that they provide access to knowledge and support in acquiring skills as well as participate in shaping attitudes, and as a consequence they contribute to the creation of human capital.

All of the factors which are included in our approach to measurement are determined by the education system. Firstly, in order to reflect educational institutions the authors assumed diagnostic variables which are based on the number of such institutions in relation to the number of inhabitants in each of the analysed cities. Secondly, they included diagnostic variables which reflect the number of students in schools on each level of education and the number of teachers working in them. Specifically, a ratio of the number of teachers in schools and preschools per ten students in each analysed city was used. These two types of diagnostic variables were grouped in accordance with the level of education into: (1) preschool education, (2) primary education and (3) secondary and post-secondary education.

Only primary education is fully obligatory which convinced the authors to add one more diagnostic variable at this level of education - the gross enrolment rate 
which reflects the ratio of the number of people who educate themselves in schools of a given level or type (irrespective of their age) to the total population whose age is appropriate for that level of schooling. The enrolment rate shows to what degree schooling is universal and thus may be used to assess the population's educational activity. In communes where the enrolment rate exceeds 1 , there are more students in primary and "gimnazjum" than there are inhabitants in the group age relevant to that level of education.

The next diagnostic variable which the authors used for assessing the educationbased potential for development of analysed cities is based on the expenditure of those cities on preschools (expenditure in section 80104 of the budget classification), primary schools (expenditure in section 80101), including special primary schools (expenditure in section 80102) and "gimnazjum" (expenditure in section 80110), including the specialist ones (expenditure in section 80111).

Independently of the assumed approach and key concepts, the cause-effect relationships between education on all levels (including higher education) and the sustainable development of cities are rather typically highlighted (see for example Badea and Angheluta, 2018). Taking this into account, it seems reasonable to perceive education on all levels (including higher education) as a single development factor (see Russ, Bansal, and Parrillo, 2015).

However, the specificity of some countries - including Poland - leads to the conclusion that both the measurement of development potential as well as the analysis of their impact on the functioning of cities ought to be carried out for all levels of education, separately from higher education. This approach is justified primarily by the way in which education on various levels is organised and financed. In the case of Poland, tasks related to primary and secondary education are the responsibility of local government (communes and districts, respectively). Given that, a certain feedback may be identified - actions and expenditure on education contribute directly to the creation of human capital and, as a consequence, the development potential of cities. The situation is quite different with regard to higher education institutions (HEIs) - in this case the organisation and financing is the domain of central government even though part of the outcome of HEIs' activity contributes directly the creation of the development potential of individual cities where these institutions are located.

It also needs to be emphasised that the type of knowledge and innovations which arise from central government intervention are characterised by significant risk, indivisibility and limitations with regard to taking over the returns and benefits. The central authorities are therefore often forced to conduct fundamental research directly, through universities or through co-funding the fundamental research activities of private enterprises and to determine the principles of sharing the ensuing intellectual property with the use of patent laws and licences (May, 2000).

The educational potential of (only) higher education institutions in Poland was analysed with the use of a taxonomic measure for the period 1991-2007 (Kwiatkowski 
and Roszkowska, 2008). The analysis was based on data on the number of institutions, the number of students and the number of academic teachers. The authors came to the conclusion that the educational potential of HEIs plays a significant role in fostering national economic development. They also indicate that the educational potential increased greatly in the period of transformation, especially so in the private sector.

The above discussion led to the conclusion that data on the number of higher education institutions which are functioning in a given city should be incorporated into the synthetic measure of education-based potential for cities' development. Some of the earlier research used the number of students enrolled in the local HEIs as a proxy for the generated human capital, mainly due to the easy access to data. Research which is based on such diagnostic variables may lead to ambiguous, easily misinterpreted results - it is never possible to predict how many students will stay in the city, contributing to its development, following graduation. Some of the outcomes

Table 1. Factors and diagnostic variables of the City Education Potential index (CEP index)

\begin{tabular}{|c|c|c|c|c|}
\hline FACTOR & DIAGNOSTIC VARIABLE & SYMBOL & NATURE & WEIGHT \\
\hline \multirow[t]{2}{*}{ Preschools } & $\begin{array}{l}\text { The number of preschools per } 1,000 \\
\text { inhabitants }\end{array}$ & $\mathrm{X}_{1}$ & stimulant & 0.10 \\
\hline & $\begin{array}{l}\text { The number of teachers per } 10 \text { children } \\
\text { in preschools }\end{array}$ & $\mathrm{X}_{2}$ & stimulant & 0.10 \\
\hline \multirow{3}{*}{$\begin{array}{l}\text { Primary schools } \\
\text { and 'gimnazjum' } \\
\text { (pre-secondary } \\
\text { stage) }\end{array}$} & $\begin{array}{l}\text { The number of primary schools and } \\
\text { 'gimnazjum' per } 1,000 \text { inhabitants }\end{array}$ & $X_{3}$ & stimulant & 0.05 \\
\hline & $\begin{array}{l}\text { The number of teachers per } 10 \text { children } \\
\text { in primary schools and gymnasia }\end{array}$ & $\mathrm{X}_{4}$ & stimulant & 0.05 \\
\hline & $\begin{array}{l}\text { The gross enrolment rate for primary } \\
\text { schools and gymnasia }\end{array}$ & $\mathrm{X}_{5}$ & stimulant & 0.10 \\
\hline \multirow{4}{*}{$\begin{array}{l}\text { Secondary and } \\
\text { post-secondary } \\
\text { schools }\end{array}$} & $\begin{array}{l}\text { The number of secondary schools per } \\
1,000 \text { inhabitants }\end{array}$ & $\mathrm{X}_{6}$ & stimulant & 0.05 \\
\hline & $\begin{array}{l}\text { The number of teachers per } 10 \text { students } \\
\text { in secondary schools }\end{array}$ & $\mathrm{X}_{7}$ & stimulant & 0.05 \\
\hline & $\begin{array}{l}\text { The number of post-secondary schools } \\
\text { per } 1,000 \text { inhabitants }\end{array}$ & $X_{8}$ & stimulant & 0.05 \\
\hline & $\begin{array}{l}\text { The number of teachers per } 10 \text { students } \\
\text { in post-secondary schools }\end{array}$ & $\mathrm{X}_{9}$ & stimulant & 0.05 \\
\hline Expenditure & $\begin{array}{l}\text { Expenditure in sections: } 80101 ; 80102 \text {; } \\
80110 ; 80111 ; 80104 \text { from city budgets } \\
\text { per } 1,000 \text { inhabitants }\end{array}$ & $X_{10}$ & stimulant & 0.20 \\
\hline \multirow[t]{2}{*}{$\begin{array}{l}\text { Higher education } \\
\text { institutions }\end{array}$} & $\begin{array}{l}\text { The number of HEIs per } 1,000 \\
\text { inhabitants }\end{array}$ & $\mathrm{X}_{11}$ & stimulant & 0.10 \\
\hline & $\begin{array}{l}\text { The number of students per } 1,000 \\
\text { inhabitants }\end{array}$ & $X_{12}$ & stimulant & 0.10 \\
\hline
\end{tabular}

Source: prepared by the authors. 
of HEI's activity spill over city boundaries as information and people are mobile in today's world. This may make the attempt to assign a specific location to the development potentials generated within HEIs a difficult, if not an impossible task. To a degree the mobility of people (migrations) may have a similar effect also on the development potential which is generated in secondary and primary education, although it can be expected that the strength of this effect will be weaker and, perhaps, observable after longer time lags.

On the other hand, it is not unrealistic to expect that - to a degree - the number of students is closely correlated to the competences (knowledge, skills and attitudes) which HEIs generate.

In conclusion, the final group of diagnostic variables which we use is based on the assumption that higher education institutions contribute to the education-based potential for cities' development. Their contribution is measured by the number of HEIs as well as by the number of students in each year. Both these diagnostic variables are placed in relation to the number of inhabitants of a given city.

Table 1 presents all the factors and diagnostic variables for the City Education Potential index, indicating their nature and assumed weight - each of the factors was assumed to carry equal weight $(0.2)$ which was further allocated to diagnostic variables. Organizing multi-feature objects requires the division of features into stimulants and destimulants. As Table 1 indicates, all the diagnostic variables are assumed to be stimulants.

To determine the City Education Potential index, multivariate comparative analysis was used. Stimulants were standardized and then taxonomic indexes based on Euclidean distances were calculated.

\section{Research results and discussion}

\subsection{Analysis by size category}

The City Education Potential Index was calculated for all urban communes in Poland from 2013 to 2016 using the factors and diagnostic variables outlined in Table 1. Afterwards the communes were ranked in accordance with the CEP index for each of the years as well as with the average of CEP index for the four years included in the analysis $\left(\mathrm{CEP}_{2013-2016}\right)$. The highest education-based potential for development in 2016 was observed in Podkowa Leśna (3,874 inhabitants in 2016), Warsaw $(1,748,916$ inhabitants), Józefów (20,294 inhabitants), Łeba (3,760 inhabitants) and Sandomierz (24,124 inhabitants). Podkowa Leśna is ranked first in all the analysed years while Warsaw moved up from 9th in 2013, mostly due to newly created preschools and increased expenditure on education.

Looking at the four-year average $\left(\mathrm{CEP}_{2013-2016}\right)$, small cities (up to 20,000 inhabitants) hold four of the top 10 places (including first and second), medium cities 
(between 20,000 and 100,000 inhabitants) occupy four of the other top 10 positions while the large cities (above 100,000 inhabitants) - the remaining two. Table 2 shows the values of the City Education Potential index for the top 10 cities in each of the size categories according to the four-year average $\left(\mathrm{CEP}_{2013-2016}\right)$. Additionally, it indicates the median value of the $\mathrm{CEP}_{2013-2016}$ index for each of the size categories.

Table 2. City Education Potential Index in Polish cities by size category

\begin{tabular}{|c|c|c|c|c|c|c|c|c|}
\hline $\begin{array}{l}\text { Size } \\
\text { category }\end{array}$ & Rank & City & $\mathrm{CEP}_{2013}$ & $\mathrm{CEP}_{2014}$ & $\mathrm{CEP}_{2015}$ & $\mathrm{CEP}_{2016}$ & $\mathrm{CEP}_{2013-2016}$ & $\begin{array}{c}\mathrm{CEP}_{2013-2016} \\
\text { median } \\
\text { value } \\
\text { per size } \\
\text { category }\end{array}$ \\
\hline \multirow{10}{*}{ 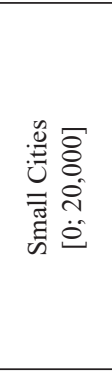 } & 1 & Podkowa Leśna & 0.6287 & 0.6847 & 0.6803 & 0.6435 & 0.6593 & \multirow{10}{*}{0.2528} \\
\hline & 2 & Łeba & 0.2631 & 0.3913 & 0.3793 & 0.3737 & 0.3519 & \\
\hline & 3 & Sucha Beskidzka & 0.2060 & 0.3769 & 0.3524 & 0.3556 & 0.3227 & \\
\hline & 4 & Karpacz & 0.1972 & 0.3652 & 0.3693 & 0.3574 & 0.3223 & \\
\hline & 5 & Garwolin & 0.2028 & 0.3646 & 0.3584 & 0.3569 & 0.3207 & \\
\hline & 6 & Ustroń & 0.2043 & 0.3842 & 0.3442 & 0.3364 & 0.3173 & \\
\hline & 7 & Stoczek Łukowski & 0.1882 & 0.3494 & 0.3507 & 0.3512 & 0.3099 & \\
\hline & 8 & Przeworsk & 0.1886 & 0.3498 & 0.3472 & 0.3464 & 0.3080 & \\
\hline & 9 & Łaskarzew & 0.1968 & 0.3513 & 0.3393 & 0.3435 & 0.3077 & \\
\hline & 10 & Rawa Mazowiecka & 0.1917 & 0.3470 & 0.3396 & 0.3485 & 0.3067 & \\
\hline \multirow{10}{*}{ 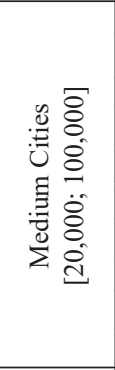 } & 1 & Sandomierz & 0.2437 & 0.3726 & 0.3590 & 0.3716 & 0.3367 & \multirow{10}{*}{0.2546} \\
\hline & 2 & Józefów & 0.1957 & 0.3592 & 0.3816 & 0.3773 & 0.3285 & \\
\hline & 3 & Siedlce & 0.2112 & 0.3646 & 0.3538 & 0.3614 & 0.3227 & \\
\hline & 4 & Puławy & 0.2073 & 0.3619 & 0.3476 & 0.3552 & 0.3180 & \\
\hline & 5 & Sopot & 0.1946 & 0.3558 & 0.3537 & 0.3550 & 0.3147 & \\
\hline & 6 & Ostrołęka & 0.1956 & 0.3552 & 0.3504 & 0.3558 & 0.3143 & \\
\hline & 7 & Konin & 0.1928 & 0.3547 & 0.3473 & 0.3487 & 0.3109 & \\
\hline & 8 & Nowy Sącz & 0.1951 & 0.3562 & 0.3476 & 0.3426 & 0.3104 & \\
\hline & 9 & Skierniewice & 0.1815 & 0.3490 & 0.3515 & 0.3513 & 0.3083 & \\
\hline & 10 & Zamość & 0.1809 & 0.3499 & 0.3476 & 0.3497 & 0.3070 & \\
\hline \multirow{10}{*}{ 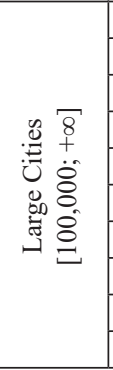 } & 1 & Warszawa & 0.2022 & 0.3706 & 0.3649 & 0.3855 & 0.3308 & \multirow{10}{*}{0.2721} \\
\hline & 2 & Poznań & 0.1972 & 0.3655 & 0.3593 & 0.3695 & 0.3229 & \\
\hline & 3 & Olsztyn & 0.1871 & 0.3557 & 0.3519 & 0.3634 & 0.3145 & \\
\hline & 4 & Płock & 0.1930 & 0.3492 & 0.3470 & 0.3448 & 0.3085 & \\
\hline & 5 & Rzeszów & 0.1743 & 0.3502 & 0.3539 & 0.3516 & 0.3075 & \\
\hline & 6 & Białystok & 0.1816 & 0.3500 & 0.3448 & 0.3534 & 0.3075 & \\
\hline & 7 & Opole & 0.1791 & 0.3499 & 0.3451 & 0.3530 & 0.3068 & \\
\hline & 8 & Lublin & 0.1801 & 0.3487 & 0.3403 & 0.3446 & 0.3034 & \\
\hline & 9 & Wrocław & 0.1677 & 0.3446 & 0.3448 & 0.3515 & 0.3022 & \\
\hline & 10 & Gdańsk & 0.1721 & 0.3482 & 0.3422 & 0.3459 & 0.3021 & \\
\hline
\end{tabular}

Source: prepared by the authors.

Analysing the values of the CEP index, one can observe that even though small urban communes hold a considerable number of top positions, the median value of $\mathrm{CEP}_{2013-2016}$ is the highest for large urban communes. This implies the smaller differentiation of education-based potential for development in large cities compared to 
medium and small ones, as seen in Figure 1, which shows the dependence between the number of inhabitants of cities and their education-based potential for development. For the sake of clarity this includes all cities apart from Warsaw, which has close to 1.75 million inhabitants.
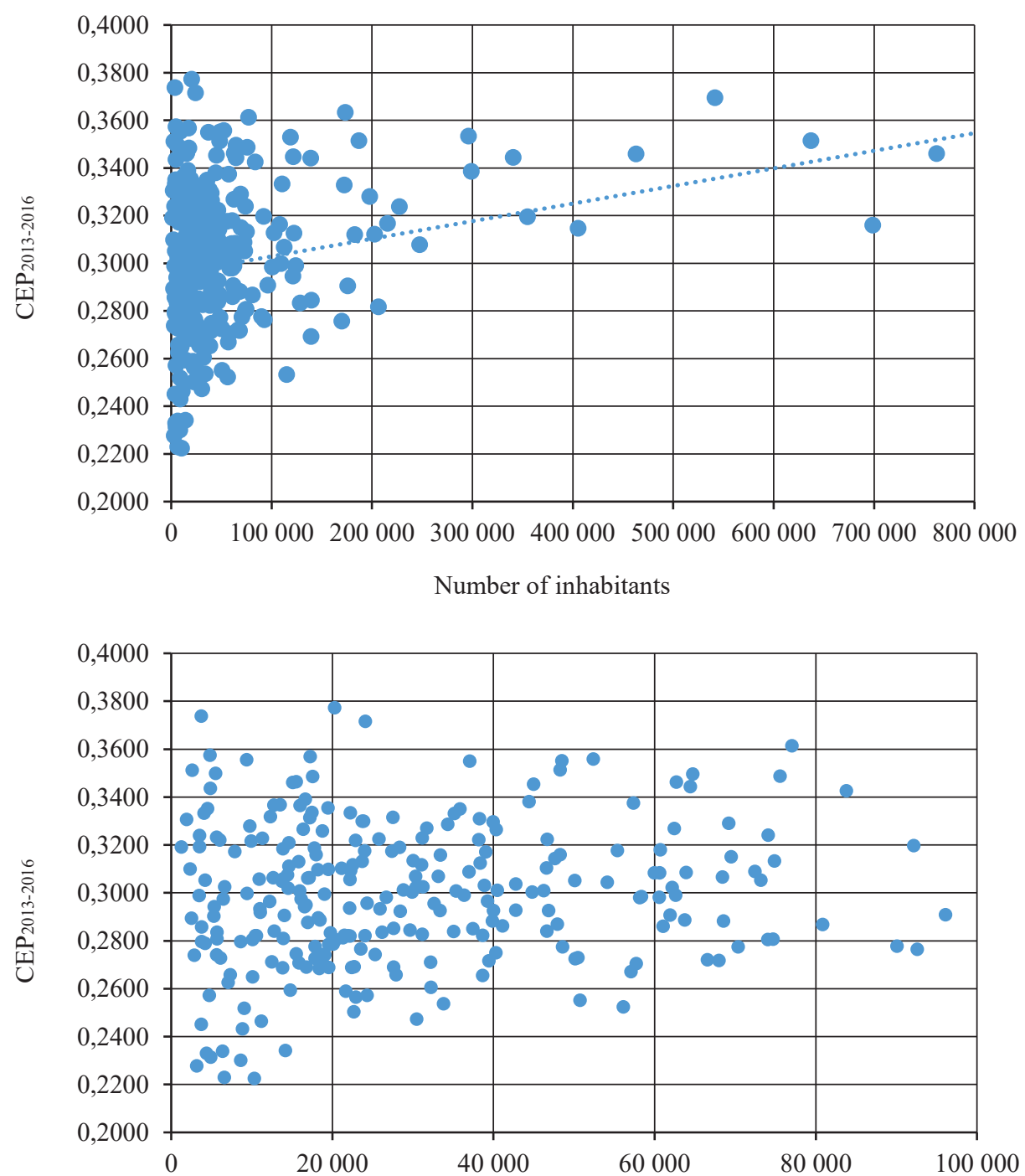

Number of inhabitants

Fig. 1. City size and education-based potential for development

Source: prepared by the authors. 
One other observation is that there is a positive dependence between city size and the level of the $\mathrm{CEP}_{2013-2016}$ index, although this is not a very strong correlation / relationship.

The next aspect of the analysis concentrates on the role of each of the factors and diagnostic variables in determining education-based potentials for the development of cities in each size category. Figures 2, 3 and 4 show how significant each of the diagnostic variables is in determining the values of the $\mathrm{CEP}_{2013-2016}$ index for cities ranked in the top 10 in each of the analysed size categories.

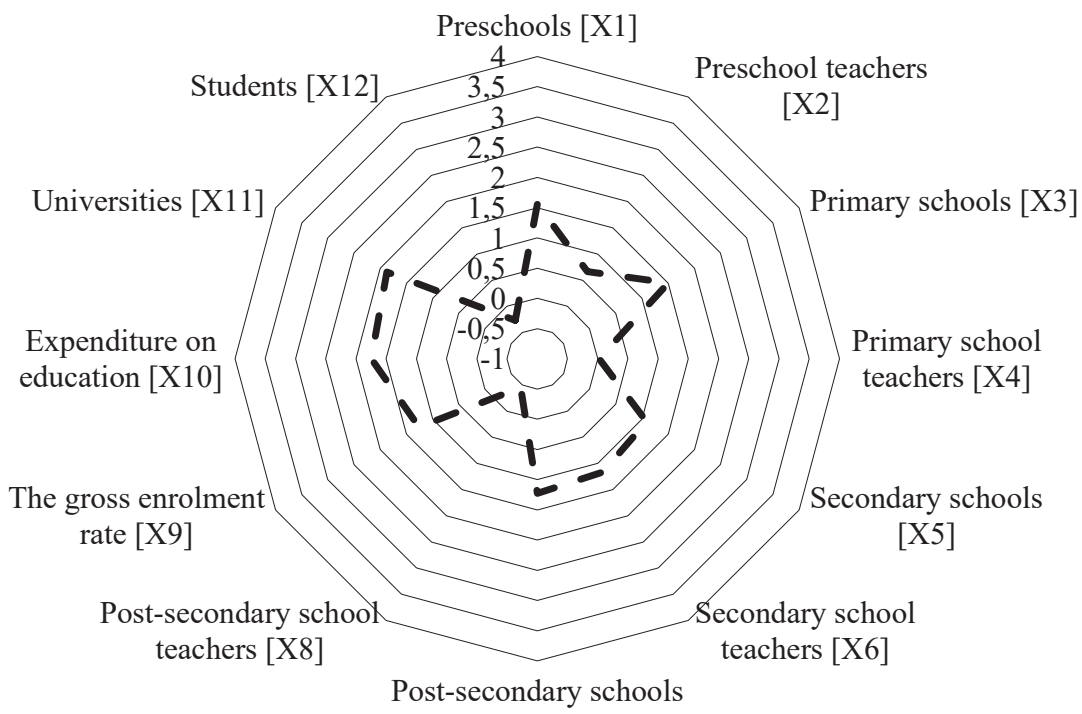

[X7]

Fig. 2. Determinants of education-based potential for the top 10 small cities

Source: prepared by the authors.

The number of preschools, primary schools, pre-secondary ('gimnazjum'), secondary and post-secondary schools per 1,000 inhabitants is the leading determinant of education-based potential for development in the top 10 small cities. This implies that the schools are small with few student groups. What is surprising is that the gross enrolment rate is higher in small cities than in medium-sized and large ones. Small urban communes are also characterised by the highest expenditure on primary and pre-secondary schools ('gimnazjum').

When analysing medium-sized urban communes one can see the growing significance of the number teachers per 10 students and the decreasing importance of the number of schools. What is more, the top 10 medium-sized urban communes are characterised by the relatively high number of HEIs per 1,000 inhabitants and the relatively low number of students per 1,000 inhabitants. 


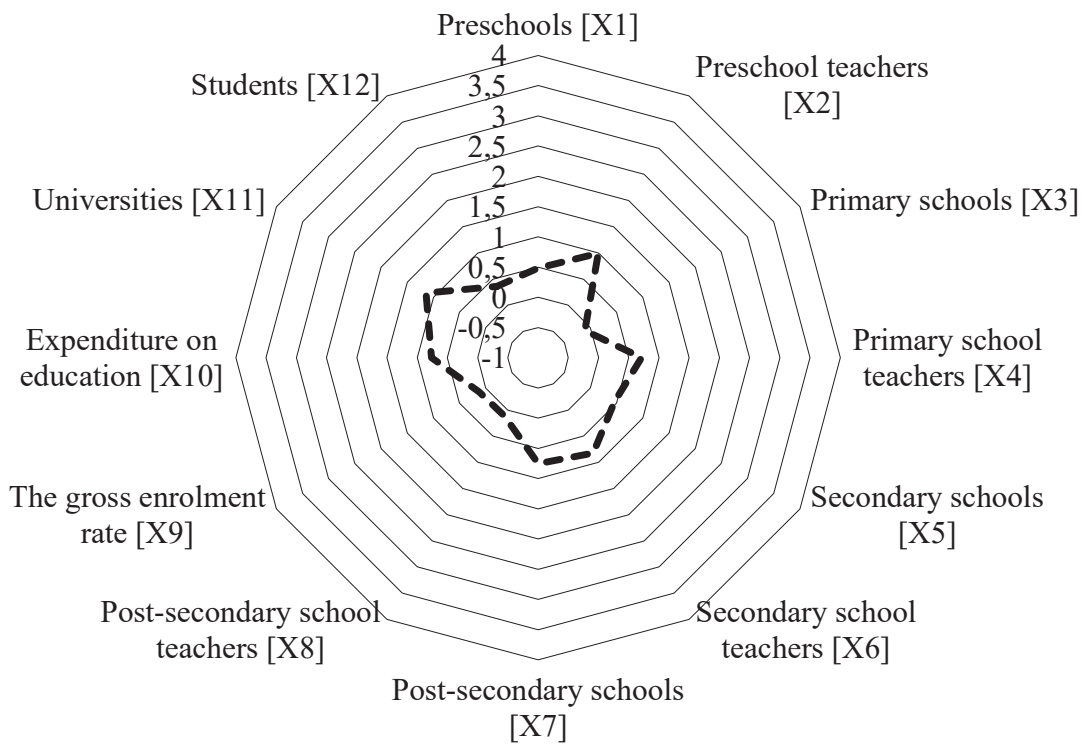

Fig. 3. Determinants of education-based potential for the top 10 medium-sized cities Source: prepared by the authors.

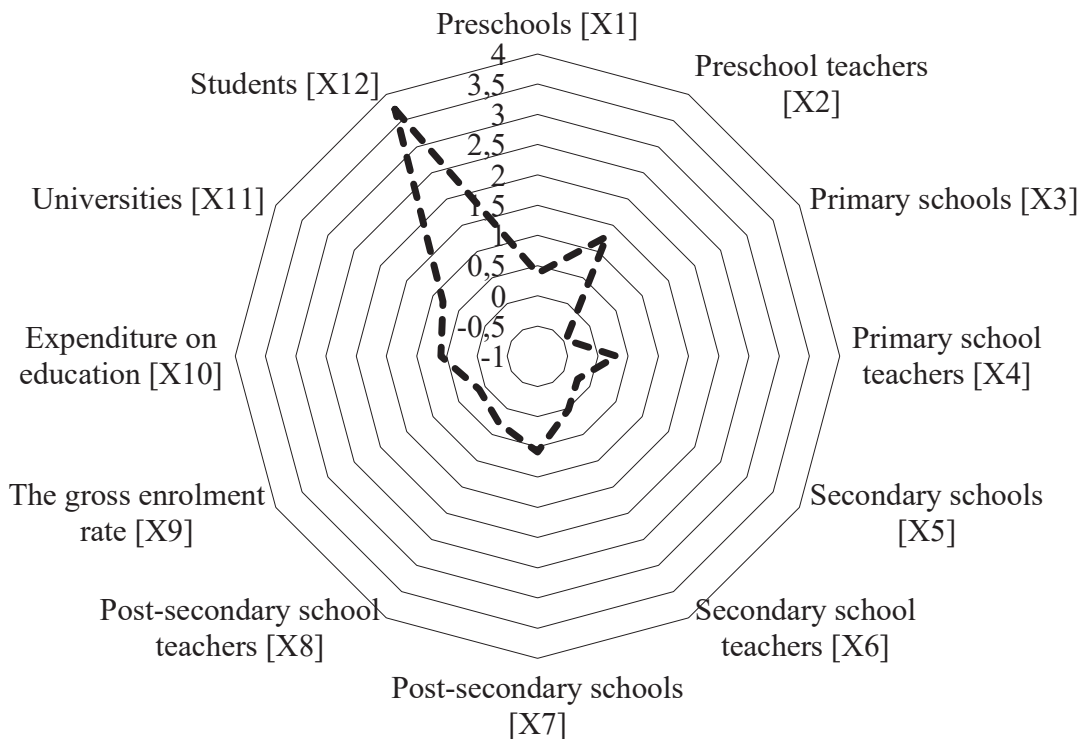

Fig. 4. Determinants of education-based potential for the top 10 large cities

Source: prepared by the authors. 
Finally, the largest urban communes are characterised by the smaller number of educational institutions relative to the population but a significantly higher teacher-student ratio in all levels of education. This implies that the schools are quite large, with numerous student groups and the tuition organised as a mass process. What is more, the large cities have by far the largest university student population which seems quite obvious given that the largest higher education institutions are located in large cities.

\subsection{Analysis by regions}

The next aspect of analysis based on the City Education Potential index relates to its geographical differentiation. Table 3 presents information on CEP index values in 2013-2016 in 48 urban communes - three urban communes with the highest value of the $\mathrm{CEP}_{2013-2016}$ index were chosen in each of the 16 Polish regions. It needs to be emphasised that not all regional capitals have the highest education-based potential for development as the stereotypical perception would suggest. This is only the case in six regions.

Table 3. Education potential of cities in Poland by region

\begin{tabular}{|c|c|c|c|c|c|c|c|c|c|}
\hline 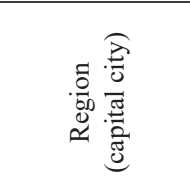 & 范 & હ્ટ & 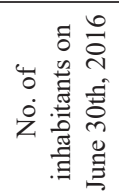 & $\overbrace{}^{\stackrel{m}{i}}$ & $\overbrace{}^{\stackrel{t}{\Delta}}$ & $\overbrace{}^{\frac{n}{i}}$ & $\overbrace{0}^{\stackrel{0}{0}}$ & 突 & 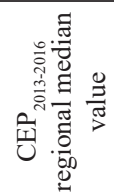 \\
\hline 1 & 2 & 3 & 4 & 5 & 6 & 7 & 8 & 9 & 10 \\
\hline \multirow{3}{*}{$\begin{array}{l}\text { dolnośląskie } \\
\text { (Wrocław) }\end{array}$} & 1 & Karpacz & 4,841 & 0.1972 & 0.3652 & 0.3693 & 0.3574 & 0.3613 & \multirow{3}{*}{0.2834} \\
\hline & 2 & Wrocław & 637,075 & 0.1677 & 0.3446 & 0.3448 & 0.3515 & 0.3447 & \\
\hline & 3 & Kłodzko & 27,554 & 0.1636 & 0.3428 & 0.3240 & 0.3315 & 0.3277 & \\
\hline \multirow{3}{*}{$\begin{array}{l}\text { kujawsko- } \\
\text { pomorskie } \\
\text { (Bydgoszcz, } \\
\text { Toruń) }\end{array}$} & 1 & Nieszawa & 1,950 & 0.1268 & 0.3424 & 0.3419 & 0.3306 & 0.3362 & \multirow{3}{*}{0.2926} \\
\hline & 2 & $\begin{array}{l}\text { Aleksandrów } \\
\text { Kujawski }\end{array}$ & 12,346 & 0.1434 & 0.3309 & 0.3264 & 0.3319 & 0.3287 & \\
\hline & 3 & Radziejów & 5,670 & 0.1507 & 0.3283 & 0.3159 & 0.3232 & 0.3195 & \\
\hline \multirow{3}{*}{$\begin{array}{l}\text { lubelskie } \\
\text { (Lublin) }\end{array}$} & 1 & Puławy & 48,526 & 0.2073 & \begin{tabular}{|l|}
0.3619 \\
\end{tabular} & 0.3476 & 0.3552 & 0.3552 & \multirow{3}{*}{0.3103} \\
\hline & 2 & Stoczek Łukowski & 2,622 & 0.1882 & 0.3494 & 0.3507 & 0.3512 & 0.3507 & \\
\hline & 3 & Zamość & 64,746 & 0.1809 & 0.3499 & 0.3476 & 0.3497 & 0.3497 & \\
\hline \multirow{3}{*}{$\begin{array}{l}\text { lubuskie } \\
\text { (Gorzów } \\
\text { Wlkp., Zielona } \\
\text { Góra) }\end{array}$} & 1 & Zielona Góra & 138,898 & 0.1488 & 0.3268 & 0.3344 & 0.3442 & 0.3306 & \multirow{3}{*}{0.2956} \\
\hline & 2 & Żary & 38,197 & 0.1466 & 0.3317 & 0.3094 & 0.3223 & 0.3158 & \\
\hline & 3 & Kostrzyn nad Odrą & 18,023 & 0.1395 & 0.3256 & 0.3134 & 0.3160 & 0.3147 & \\
\hline \multirow{3}{*}{$\begin{array}{l}\text { łódzkie } \\
\text { (Łódź) }\end{array}$} & 1 & Skierniewice & 48,304 & 0.1815 & 0.3490 & 0.3515 & 0.3513 & 0.3502 & \multirow{3}{*}{0.2924} \\
\hline & 2 & Rawa Mazowiecka & 17,596 & 0.1917 & 0.3470 & 0.3396 & 0.3485 & 0.3433 & \\
\hline & 3 & Łódź & 698,688 & 0.1390 & 0.3218 & 0.3142 & 0.3161 & 0.3151 & \\
\hline \multirow{3}{*}{$\begin{array}{l}\text { małopolskie } \\
\text { (Kraków) }\end{array}$} & 1 & Sucha Beskidzka & 9,388 & 0.2060 & \begin{tabular}{|l|}
0.3769 \\
\end{tabular} & \begin{tabular}{|l|}
0.3524 \\
\end{tabular} & 0.3556 & 0.3540 & \multirow{3}{*}{0.3171} \\
\hline & 2 & Nowy Sącz & 83,829 & 0.1951 & 0.3562 & 0.3476 & 0.3426 & 0.3451 & \\
\hline & 3 & Limanowa & 15,124 & 0.1866 & 0.3490 & 0.3349 & 0.3461 & 0.3405 & \\
\hline
\end{tabular}


Table 3, cd.

\begin{tabular}{|c|c|c|c|c|c|c|c|c|c|}
\hline 1 & 2 & 3 & 4 & 5 & 6 & 7 & 8 & 9 & 10 \\
\hline \multirow{3}{*}{$\begin{array}{l}\text { mazowieckie } \\
\text { (Warszawa) }\end{array}$} & 1 & Podkowa Leśna & 3,874 & 0.6287 & 0.6847 & 0.6803 & 0.6435 & 0.6619 & \multirow{3}{*}{0.3249} \\
\hline & 2 & Józefów & 20,294 & 0.1957 & 0.3592 & 0.3816 & 0.3773 & 0.3682 & \\
\hline & 3 & Warszawa & $1,748,916$ & 0.2022 & 0.3706 & 0.3649 & 0.3855 & 0.3678 & \\
\hline \multirow{3}{*}{$\begin{array}{l}\text { opolskie } \\
\text { (Opole) }\end{array}$} & 1 & Opole & 118,938 & 0.1791 & 0.3499 & 0.3451 & 0.3530 & 0.3499 & \multirow{3}{*}{0.3043} \\
\hline & 2 & Kędzierzyn-Koźle & 62,193 & 0.1332 & 0.3094 & 0.3043 & 0.3022 & 0.3043 & \\
\hline & 3 & Brzeg & 36,381 & 0.1116 & 0.2996 & 0.2896 & 0.2991 & 0.2991 & \\
\hline \multirow{3}{*}{$\begin{array}{l}\text { podkarpackie } \\
\text { (Rzeszów) }\end{array}$} & 1 & Rzeszów & 187,027 & 0.1743 & 0.3502 & 0.3539 & 0.3516 & 0.3509 & \multirow{3}{*}{0.3106} \\
\hline & 2 & Przeworsk & 15,556 & 0.1886 & 0.3498 & 0.3472 & 0.3464 & 0.3468 & \\
\hline & 3 & Jasło & 35,866 & 0.1867 & 0.3531 & 0.3435 & 0.3350 & 0.3392 & \\
\hline \multirow{3}{*}{$\begin{array}{l}\text { podlaskie } \\
\text { (Białystok) }\end{array}$} & 1 & Białystok & 296,310 & 0.1816 & 0.3500 & 0.3448 & 0.3534 & 0.3474 & \multirow{3}{*}{0.3044} \\
\hline & 2 & Sejny & 5,554 & 0.1654 & 0.3413 & 0.3341 & 0.3499 & 0.3377 & \\
\hline & 3 & Łomża & 62,716 & 0.1704 & 0.3361 & 0.3310 & 0.3463 & 0.3335 & \\
\hline \multirow{3}{*}{$\begin{array}{l}\text { pomorskie } \\
\text { (Gdańsk) }\end{array}$} & 1 & Łeba & 3,760 & 0.2631 & 0.3913 & 0.3793 & 0.3737 & 0.3765 & \multirow{3}{*}{0.3097} \\
\hline & 2 & Sopot & 37,089 & 0.1946 & 0.3558 & 0.3537 & 0.3550 & 0.3543 & \\
\hline & 3 & Gdańsk & 462,996 & 0.1721 & 0.3482 & 0.3422 & 0.3459 & 0.3441 & \\
\hline \multirow{3}{*}{$\begin{array}{l}\text { śląskie } \\
\text { (Katowice) }\end{array}$} & 1 & Ustroń & 16,017 & 0.2043 & 0.3842 & 0.3442 & 0.3364 & 0.3403 & \multirow{3}{*}{0.2773} \\
\hline & 2 & Cieszyn & 35,173 & 0.1857 & 0.3623 & 0.3457 & 0.3331 & 0.3394 & \\
\hline & 3 & Katowice & 299,012 & 0.1618 & 0.3392 & 0.3329 & 0.3387 & 0.3358 & \\
\hline \multirow{3}{*}{$\begin{array}{l}\text { świętokrzyskie } \\
\text { (Kielce) }\end{array}$} & 1 & Sandomierz & 24,124 & 0.2437 & 0.3726 & 0.3590 & 0.3716 & 0.3653 & \multirow{3}{*}{0.2831} \\
\hline & 2 & Kielce & 197,724 & 0.1452 & 0.3243 & 0.3212 & 0.3280 & 0.3228 & \\
\hline & 3 & $\begin{array}{l}\text { Skarżysko- } \\
\text { Kamienna }\end{array}$ & 46,656 & 0.0881 & 0.2957 & 0.2820 & 0.2841 & 0.2831 & \\
\hline \multirow{3}{*}{$\begin{array}{l}\text { warmińsko- } \\
\text { mazurskie } \\
\text { (Olsztyn) }\end{array}$} & 1 & Olsztyn & 173,599 & 0.1871 & 0.3557 & 0.3519 & 0.3634 & 0.3538 & \multirow{3}{*}{0.2914} \\
\hline & 2 & Górowo Iławeckie & 4,114 & 0.1978 & 0.3550 & 0.3384 & 0.3333 & 0.3358 & \\
\hline & 3 & Szczytno & 23,901 & 0.1730 & 0.3422 & 0.3253 & 0.3300 & 0.3277 & \\
\hline \multirow{3}{*}{$\begin{array}{l}\text { wielkopolskie } \\
\text { (Poznań) }\end{array}$} & 1 & Poznań & 541,561 & 0.1972 & 0.3655 & 0.3593 & 0.3695 & 0.3624 & \multirow{3}{*}{0.3100} \\
\hline & 2 & Konin & 75,607 & 0.1928 & 0.3547 & 0.3473 & 0.3487 & 0.3480 & \\
\hline & 3 & Leszno & 64,468 & 0.1751 & 0.3475 & 0.3377 & 0.3444 & 0.3410 & \\
\hline \multirow{3}{*}{$\begin{array}{l}\text { zachodnio- } \\
\text { pomorskie } \\
\text { (Szczecin) }\end{array}$} & 1 & Koszalin & 107,981 & 0.1425 & 0.3198 & 0.3097 & 0.3163 & 0.3130 & \multirow{3}{*}{0.2874} \\
\hline & 2 & Wałcz & 25,801 & 0.1221 & 0.3142 & 0.3090 & 0.3225 & 0.3116 & \\
\hline & 3 & Sławno & 12,674 & 0.1300 & 0.3146 & 0.3102 & 0.3063 & 0.3082 & \\
\hline
\end{tabular}

Source: prepared by the authors.

Analysing the values of the City Education Potential index calculated for urban communes in each of the Polish regions, became the basis for determining the regional differentiation with regard to the education-based potential for development in regions and identifying regions where this potential is generally greater. The highest median value of the $\mathrm{CEP}_{2013-2016}$ index is observed in mazowieckie (Warsaw) which is followed by małopolskie (Kraków), podkarpackie (Rzeszów) and wielkopolskie (Poznań). The lowest values of the $\mathrm{CEP}_{2013-2016}$ index are observed in śląskie (Katowice), świętokrzyskie (Kielce), dolnośląskie (Wrocław) and zachodniopomorskie (Szczecin). Figure 5 presents the geographical differentiation of the $\mathrm{CEP}_{2013-2016}$ index in Polish regions. 


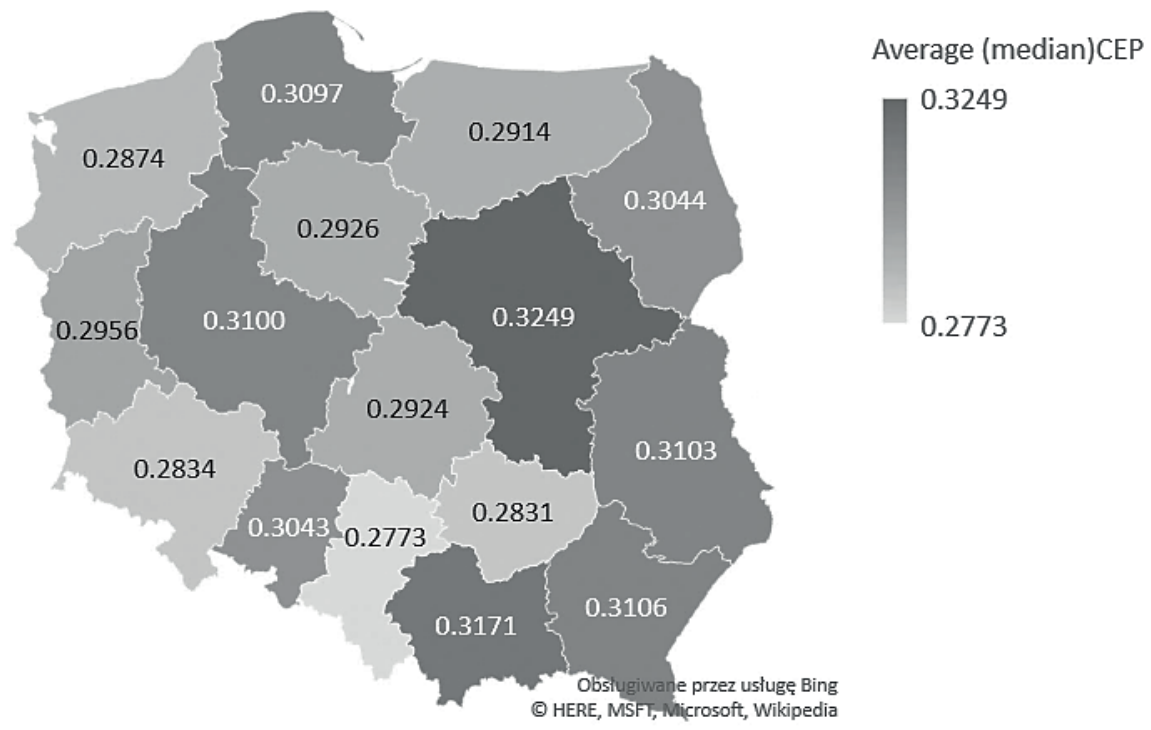

Fig. 5. Education potential of cities in Poland by region $\left(\mathrm{CEP}_{2013-2016}\right.$ median value)

Source: prepared by the authors.

\section{Conclusions}

The conditions for educational activities vary between small, medium-sized and large cities. This is illustrated first of all by the varying numbers of students per teacher which may be directly linked to the quality of educational services provided, and the efficiency with which the educational value added is generated. Analysis of data for the leading (top 10) cities in each size category shows that in the case of preschools as well as post-secondary schools, the most beneficial situation in that respect is observed in large cities, followed by medium-sized cities and small cities. However, when looking at primary schools the analysis shows that the best conditions for students exist in medium-sized cities with large cities and small cities trailing quite visibly. When it comes to secondary schools the situation is quite different with small cities achieving student-teacher ratios which are lower than in medium-sized cities and considerably lower than in large cities.

Another observation is that schools in large cities tend to be organised as centres for mass education, providing services to much larger groups of students and employing many more teachers than in small cities. This, together with the higher degree of saturation with preschools and schools (more institutions per set number of inhabitants) also results in significantly higher per capita expenditure on education in small cities. 
The taxonomic analysis also confirmed the existence of inter-regional differentiation of the education-based potential for development with cities in mazowieckie (region) achieving the highest median value of the $\mathrm{CEP}_{2013-2016}$ index and the cities in śląskie (region) the lowest. Further research is needed to provide additional insights into the relation between education-based potential for development and welfare in both cities as well as regions.

Discussing the variation of CEP index values, it needs to be emphasised that there are only slight differences in terms of the overall education-based potential for development between urban communes belonging to different size categories. This may result from the high degree of legal regulation on the central authorities' level in the sphere of education.

Finally, one need to bear in mind that apart from the system of formal education, cities are also spaces where informal education may take place. This article concentrates only on the measurable aspects of the system of formal education mainly because of greater access to data. However, in order to more fully assess the educationbased potential for development, other factors and diagnostic variables, reflecting also the informal aspect of education, ought to be taken into consideration. This will become one of main objectives of the authors' future work.

\section{Bibliography}

Badea, C., and Angheluta, P. (2018). Education as support for the urban sustainable development. Economics, Management and Financial Markets, 13(3), 327-339.

Badea, L., and Rogojanu, A. (2012). Controversies concerning the connection higher education - human capital - competitiveness. Theoretical and Applied Economics, XIX, 12(577), 125-142.

Burgess, S. (2016). Human capital and education: The state of the art in the economics of education. IZA Discussion Paper, 9885, Bonn: IZA.

Czapiewski, K. (2013). Edukacja jako czynnik rozwoju Mazowsza. Warszawa: Mazowieckie Biuro Planowania regionalnego w Warszawie.

Drucker, P. (1994). The Age of Social Transformation. The Atlantic Monthly. November, 53-58.

Eriksson, L., and Forsberg, A. (2010). The part played by popular education in local development processes in suburban and rural areas of Sweden. International Journal of Lifelong Education, 29 (3), 323-341.

Faggian, A., and McCann, P. (2009). Human capital and regional development. In R. Capello, and P. Nijkamp (Eds.), Handbook of Regional Growth and Development Theories (pp. 133-151), Cheltenham: Edward Elgar Publishing Ltd.

Gennaioli, N., La Porta, R., Lopez-de-Silanes, F., and Shleifer, A. (2011). Human capital and regional development. National Bureau of Economic Research Working Papers, (17158), Cambridge: NBER.

Gołaszewska-Kaczan, U. (2014). Działania podnoszące poziom kapitału ludzkiego w nowej perspektywie finansowania 2014-2020. Optimum. Studia Ekonomiczne, 6(72), 91-104.

Jona, G. (2015). Determinants of Hungarian sub-regions' territorial capital. European Spatial Research and Policy, 22(1), 101-119.

Joshi, P. (2017). A perspective on education's importance for urban development. European Journal of Education, Research, Development and Policy, 52, 421-426. 
Kwiatkowski, E. and Roszkowska, S. (2008). Rozwój i zróżnicowanie regionalne szkolnictwa wyższego w Polsce. Gospodarka Narodowa, 4, 1-20.

Lazzeretti, L., and Tavoletti, E. (2005). Higher education excellence and local economic development: the case of the Entrepreneurial University of Twente. European Planning Studies, 13(3), 475-493.

May, C. (2000). Foundations of Weightlessness: the Knowledge Economy, the State and Economic Development. In A. Kukliński, and W. Orłowski (Eds.), The Knowledge-based Economy: The Global Challenges of the 21st Century (pp. 69-80). Warszawa: Komitet Badań Naukowych.

Orankiewicz, A., and Turała, M. (2019). Czynniki rozwoju miast w Polsce - wstęp do badań. In J. Danielewicz, and D. Sikora-Fernandez (Eds.), Zarządzanie rozwojem współczesnych miast (pp. 175188). Łódź: Wydawnictwo Uniwersytetu Łódzkiego.

Przygodzki, Z. (2015). Kapitał terytorialny w zintegrowanym planowaniu rozwoju. Koncepcje współpracy. Barometr Regionalny, 13(4), 29-33.

Russ, M., Bansal, G., and Parrillo, A. (2015). The "Knowledge City" and the "Experience City": The main, mediating, and moderating effects of education on income and economic inequality. Journal of the Knowledge Economy, Springer; Portland International Center for Management of Engineering and Technology (PICMET), 8(3), 804-829.

Stępień, S., and Poszwa, G. (2016). Edukacja jako istotny składnik kapitału ludzkiego wpływający na zróżnicowanie regionalne. Roczniki Ekonomiczne Kujawsko-Pomorskiej Szkoły Wyższej w Bydgoszczy, 9, 447-476.

Van Winded, W., van der Berg, L., and Pol, P. (2007). European cities in the knowledge economy: Towards a typology. Urban Studies, 44(3), 525-549. 